\title{
Food bowls and dust bowls: irrigated food production in arid Australia
}

\author{
F. Rochford \\ La Trobe University, Australia
}

\begin{abstract}
Australia's food security is partially attributable to extensive irrigation networks, drawing on major rivers and groundwater resources, particularly in the arid Murray-Darling Basin. However, a history of overallocation and protracted drought has forced caps on extractions, reallocation of water to alternative uses, and contraction of irrigation networks. Agreements between the federal and state governments paved the way for an attempt to centralise water allocation frameworks, and an attempt to integrate water management through an overarching Murray-Darling Basin Plan.

This paper considers the contentious development of the Murray-Darling Basin Plan, which proposes deep cuts to irrigation extraction in some irrigation regions. Outrage at the perceived failure of the Plan to balance environmental, social and economic priorities has forced its deferral, and the management of the Murray-Darling Basin and the development and implementation of the Basin Plan has been referred to a Senate Standing Committee on Rural Affairs and Transport. The Committee's terms of reference illustrate the tension between the environmental and food production demands on water in the Basin - the Committee is tasked in particular with the assessment of the implications of the proposed plan for agriculture and food production, sustainable productivity and viability, and the social and economic impacts of the proposed changes.

In particular, this paper draws upon the experience of the development of the Plan to assess the Australia's capacity to develop a useful conception of balance between environmental and food production uses of water.

Keywords: irrigation, environment, drought, food production.
\end{abstract}




\section{Introduction}

The Murray-Darling Basin is the most important agricultural region in Australia. Eighty-four percent of the land in the Basin is used for agriculture. Of that, $2.3 \%$ is used for irrigated agriculture. (ABS/ABARE/BRS [1]) However, that small area is responsible for disproportionately large economic returns (Hajkowicz et al. [2]). The Basin directly supports around 17\% of Australia's population (ABS/ABARE/BRS [1] 11).

However, current and projected reforms to Australian water allocation and management will have an adverse impact on the existing water infrastructure in Australian irrigation regions, circumscribing them in extent, if not in standard (Northern Victorian Irrigation Renewal Project [3]). Irrigation regions in Victoria will be diminished according to the amount of water share on the channel. Further, irrigators' water security has been and will be further adversely affected by the reforms. Whilst rhetoric supporting drastic cuts has diminished since a ten year drought was followed by widespread flooding, early political indications signalled 'significant cuts in water use' (Victorian Farmers Federation [4]). It was suggested by the Wentworth Group of Concerned Scientists in particular that some irrigators in the Murrumbidgee region would have their water rights cut by $65 \%$ (ABC [5]).

Long term and significant reform is proposed in particular as a result of the projected development of the Murray-Darling Basin Plan. At the moment the plan remains inchoate, having been made politically unpalatable by the extraordinarily negative response to initial proposals for cuts in water allocation (Lloyd, [6]), and less necessary by massive flooding across the Basin (Lloyd [7]). Nevertheless it is still anticipated that a Plan will be released, and that the process of reducing water extractions in the Basin will continue.

\section{The reform agenda}

There has been a longstanding and generally held view that the Murray-Darling Basin is overallocated - that is, the amount being extracted from the Basin for consumptive uses is damaging riverine and floodplain health and aquifer viability, and threatening the long term security of consumptive users. This is difficult to assess; whereas water extractions on many rivers are metered and paid for, and bores in some regions are licensed, metered and paid for, this is not the case for all overland flows or forestry extractions.

During the 1990s an attempt was made to assess the level of extraction. The Murray-Darling Ministerial Council, in an audit of water use (Murray-Darling Basin Ministerial Council [8]), confirmed increasing levels of diversions from rivers, and a corresponding decline in river health. This was attributed to expansion in some agricultural industries, mainly in the relatively undeveloped upper reaches of the Basin - in Queensland and northern New South Wales. Existing systems of allocation would have allowed additional extractions of a further fifteen per cent. If that occurred, the Council concluded, existing rights of irrigators would be rendered less secure, the capacity of storages to deliver a 
reliable supply during extended droughts would be reduced, and river health problems would be exacerbated. (Murray-Darling Basin Ministerial Council [9] 9). A cap of water extraction was accepted by all Basin states, and a process of bringing unaccounted extraction activities under the cap began. Extractions were capped at the volume of water that would have been diverted under 1993-94 levels of diversion. (Murray-Darling Basin Ministerial Council [10] viii). Subsequent state-based programs were implemented, resulting in reduction in water use and questions about the long term viability of irrigation districts (Department of Sustainability and Environment [11]; Department of Sustainability and Environment [12]).

After the implementation of the Cap, however, a worsening and lengthening drought increased the political impetus for a national water framework, and the Federal government took the opportunity to leverage a compromise with the Australian states to take control of water management in the Murray-Darling Basin. In 2008 the Water Act 2007 (Cth) commenced operation, intended to deliver the Commonwealth's $\$ 10.05$ billion National Plan for Water Security. The Act was intended to enable water resources in the Basin to be managed in the national interest, optimising environmental, economic and social outcomes. Constitutional impediments to the Act, originating from the States' Constitutional power over water, were dealt with through the intergovernmental Memorandum of Understanding on Murray-Darling Basin Reform (Council of Australian Governments [13]). This was aimed at whole-of-basin management of the Murray-Darling Basin, and was hailed as 'historic agreement ...marking a new era of national leadership for Australia's most important food production region' (Wong, We'll get water right [14] 17).

The reforms also create a new set of institutions, such as the National Water Commission, and gives new legal form to old institutions, replacing the MurrayDarling Basin Commission with the Murray-Darling Basin Authority, and establishing it as a body corporate accountable to the Commonwealth Minister. These bodies set about their own tasks of auditing extraction, and more particularly, attempting to define the amount that must be returned to 'the environment' in order to restore eco-system health. The response was to be contained in a new Murray-Darling Basin Plan; a legal enforceable Plan that sets 'environmentally sustainable' (Water Act 2007 s.23(1)) limits on extraction based on the best available scientific knowledge. The new level of extraction must not compromise each water resource's key environmental assets, key ecosystem functions, the productive base or key environmental outcomes (Murray-Darling Basin Authority [15] 15). The 'productive base' is the capacity (as opposed to the actual use) of the water resource for the range of uses including 'supporting environmental assets and ecosystem functions, irrigation, drinking water for people and animals, swimming, fishing and boating' (Murray-Darling Basin Authority [15] 18). 'Capacity' includes attributes, such as water quality.

In determining the level of take, the Basin Plan had be formulated by reference to, inter alia, the principles of ecologically sustainable development, on the basis of the best available scientific knowledge and socio-economic analysis, having regard to the consumptive and other economic uses of water resources, 
and to social, cultural, indigenous and other public benefit issue (Water Act 2007 s.21(4)) It had been acknowledged that, as a consequence of the implementation of the Basin Plan, irrigators would have access to water diminished.

However, the Murray-Darling Basin Authority's release of a Guide to the Proposed Basin Plan (Murray-Darling Basin Authority [16]) proposed such significant cuts to water entitlements that political backlash ensued. Copies of the Guide were burned in protest (Cooper [17]). The capacity of the Authority, under one interpretation of the Water Act, to balance environmental, economic and social objectives was called into question (Wilson [18]), and the Chair of the Authority resigned (Ker [19]). A real question arose as to whether the Act, on its proper construction, required the Authority to privilege environmental over all other concerns, although reliable commentary suggested that it did (Kildea and Williams [20]).

\section{Balancing environmental, economic and social imperatives}

The management of the Murray-Darling Basin and the development and implementation of the Basin Plan has been referred to a Senate Standing Committee on Rural Affairs and Transport (Senate, Parliament of Australia [21]). The Committee's terms of reference illustrate the tension between the environmental and food production demands on water in the Basin - the Committee is tasked in particular with the assessment of the implications of the proposed plan for agriculture and food production, sustainable productivity and viability, and the social and economic impacts of the proposed changes. It is currently hearing submissions on the impact of the various projects being implemented to achieve Basin priorities, including market solutions, infrastructure solutions, purchase of water entitlements and other methods of reduction of extractions. In the interim, state solutions continue, including the closure of irrigation districts and the contraction of irrigation infrastructure.

Overall, however, the mechanisms by which 'social' objectives can be assessed in a project of this magnitude are limited. The Murray-Darling Basin Authority was criticised for inadequate consultation of affected communities; although the Guide to the Proposed Plan was intended to be the commencement of the consultative process, given the view of the Authority that environmental outcomes were prioritised over economic and social priorities the communities with whom consultation was to be effected did not consider the consultation to be real. Rather, the consultation was considered to be an ex post facto justification of the position of the Authority.

The Senate Standing Committee is taking a generally consultative approach by accepting contributions from affected individuals, groups and communities, and conducting community meetings. Submissions to the inquiry include written and oral submissions and the usual indicia of democratic participation. It is submitted, however, that this process masks serious deficiencies in Australian realpolitik because of current limitations in public policy formation in Australia, which privileges economic formulation of principles over other, softer (and harder) value questions. 


\section{Reconceptualising the economic and the agricultural}

Australian concern over water is episodic and water scarcity and overabundance occurs on a centennial timescale. Australian agricultural fortunes follow a similar trajectory, unless water security concerns are mitigated by major infrastructure. Substantial expensive infrastructure is required both for water supply and for flood mitigation, but the Australian inland is sparsely populated and cannot afford to pay for this infrastructure on a user-pays basis on current cost projections. For the majority of the population, Australian food security is at present of marginal concern; agricultural produce in Australia is destined primarily for the export market, and scarcity of food in Australia is virtually unknown. In public debate this can be converted into the proposition that much of Australian agriculture is not domestically necessary - because the food is destined for export. Where water is scarce, the notion of 'exporting' it through produce is anathematised, but Australia is a gross virtual water exporter, primarily in relation to trade in livestock and livestock products (Hoekstra [22]). There is an enduring perception that Australian agriculture is unnecessary and damaging to the environment. Moreover, it is considered to be of diminishing economic importance. In rural policy, the reduced viability of individual farmers can be resolved by the market and by 'rural adjustment' programs, leaving land to be purchased by 'more efficient' users, or in cases in which environmental policies have forced rural readjustment, acquisition by the state. This is in contrast to current projections which encourage business investment in Australian water, land and some rural commodities (Sprague [23]).

Although Australian rural water has been considered a marketised product for many years, and is available on a user-pays basis, most non-rural users do not consider it a property right and have no natural aversion to its appropriation by state action. Appropriation of private water 'rights' does not, for them, raise issues of distributive justice. In articulating the effects of water reforms in Australia, irrigators have found that, whereas the 'social' aspect of a right to water is an objective of the National Water Initiative (NWI) (MDBA 2010b), this has remained a tentative and attenuated right, largely defined by optimisation processes - so that 'water markets and trading are making a major contribution to the achievement of the NWI objective of optimising the economic, social and environmental value of water' (NWC 2010, v) (Rochford [24]).

The provision of water to rural communities is considered to be an economic, not a social question. It is to be resolved by long-standing neo-liberal practices of marketisation, which will inevitably privilege higher value - urban - use, and will result in the diminution of irrigation infrastructure. The return of water to 'the environment' as an entity distinct from rural land is an ill-defined process, particularly when the water is constituted in massive overland flows. The intractable problems of ensuring floodplain and riverine flooding to ensure ecosystem revival but not resulting in urban damage, and the problem of securing water for consumptive use in Australia's long dry periods but not diminishing downstream flows, are issues well-known to irrigators and scientists, 
but are not considered by a public whose concern is generated by outdoor watering bans in urban streets, and are not amenable to easy policy formulation.

In this policy environment, irrigators' concerns are conceptualised as an entirely economic question, and the ancillary concerns of maintaining a viable irrigated agriculture sector, and the reliability of domestic food supplies, is similarly a question of trade. What cannot be produced can be purchased. The common interest of the nation in maintaining viable food resources, and the distributional justice issues of severing infrastructure and water resources to parts of the population are silent arguments, because they do not fit within the conceptual framework for policy formation.

Similarly, the process of policy formation in a highly politicised environment such as water resource management invites responses that are defensible as 'inevitable' because they are the product of technical formulation by experts. Constanza notes that a necessary precondition of shifting from public opinion to public judgment is bridging the gap between expert knowledge (what Yankelovich (citing Habermas) calls the "culture of technical control") and the public. Information in the modern world is compartmentalized and controlled by various technical elites who do not communicate with each other. The result is that experts from various fields hold contradictory opinions and the public holds inconsistent and volatile opinions. Coming to judgment is the process of confronting and resolving these inconsistencies by dissolving the barriers between the mutually exclusive compartments into which information has been put (Constanza [25]).

This process is capable of manipulation. Policy-makers in Australia are currently guided primarily by the technical information provided by scientists, but more particularly by the modelling of the effects of policies by economists. Government agencies are predisposed to adopt economic modelling solutions in preference to issues related to justice, because it cloaks decisions with apparent neutrality.

\section{The future of farming in Australia - or what is to be done with all this land?}

Farmers in Australian are an important repository of a particular type of information - information about the conditions under which food and fibre production will continue to be viable in Australia, and about the history of constraints on food and fibre production. A precondition of 'coming to judgment' is dissolving the barriers between policy makers and those affected by their policies. Farmers are also, arguably, critical to any reasonable solution to a range of environmental problems (Howden and O'Leary [26]; Ugalde et al. [27]). It is anticipated that their importance will increase with projected effects of climate change, as the potential of agricultural land to provide carbon offsets is massive. Similarly, Australia's obligations to sustain biodiversity are reliant to a great extent on the co-operation of owners of agricultural land. However, agriculture in Australia bears disproportionately the cost of compliance with various environmental outcomes. 
Australian farmers operate in conditions of low (Adamson et al. [28] 4), extremely variable rainfall, (Carberry, et al. [29]) and farmers' knowledge of climate variability is sourced from both long-term individual records and scientific publications. Agriculture as an industry is at the frontline of response to any climatic change, because farming enterprises have to respond rapidly to change through adaptation responses such as altering irrigation regimes, altering pasture mix, making cropping decisions, destocking, or exploring alternative land use options, including conservation. Unlike most other major agricultural producers, Australia does not cushion the effects of unsuccessful agricultural decisions with large subsidies; Australian farmers have the lowest level of subsidy in the world, aside from New Zealand farmers. (Department of Foreign Affairs and Trade [30]; Carberry et al. [29]; OECD [31]) Conversely, farm subsidies in the United States alone include conservation subsidies, disaster subsidies, commodity subsidies, and crop insurance premium subsidies, the totals of which in 2009 amounted to over \$US245 billion. (Environmental Working Group [32]). The European Union similarly subsidises its farmers, although with a different mix of subsidies - including subsidisation of agriculture's 'multifunctionality' (Abler [33], Cocklin et al. [34]). This in itself presents a major cost to Australian farmers, who must compete in a global market and take global commodity prices which are artificially suppressed by other major producers.

Conversely, environmental strategies unassociated with the productive output of a particular enterprise attract significant critique from farmers, because they potentially impose a cost on individuals for a return to society as a whole. This is not an unreasonable critique. It is the basis of constitutional protection in many common law countries that is 'designed to bar Government from forcing some people alone to bear public burdens which, in all fairness and justice, should be borne by the public as a whole.' (Armstrong v United States [35]). Constitutional protections exist in most major democracies from expropriation of individual property without compensation.

On a global scale, where subsidisation of agriculture exists, policy mechanisms for substitution of existing farm commodity subsidy programs with water conservation, afforestation and carbon sequestration schemes are available (Callaway and McCarl [36]). The decoupling of commodity prices from water policy formation represents a failure on the part of policy commentators to understand the reality within which farmers in Australia are forming their preferred conservation responses.

Conversely, a policy mix which correctly assesses the diverse motivations of farmers is capable of achieving both conservation values and addressing individual concerns.

The motivation profile of farmers significantly influences investment decisions. Policy design that considers 'soft values', takes advantage of farmers' intrinsic motivation for conservation and facilitates altruistic behaviour may therefore be more effective than policy that ignores these factors (Greiner and Gregg [37]). 


\section{Conclusion}

Consultation in Australian water reform is becoming treacherous. Scientific certainty and economic modelling are preferred drivers of reform, because they allow governments to shield themselves from the social effects of hard decisions. Where consultation is carried out on that basis, however, it is perceived to be a sham, because the conclusions have already been formulated, and the knowledge and ways of seeing of the irrigator are silenced unless they are consistent with the policy infrastructure. Social outcomes are considered to be processes of optimisation, and the tools for assessing them are likely to be quasi-neutral modelling approaches favoured by economists. Questions of distributive justice, arising through the reallocation of natural resources, questions of social justice, arising through the decline of rural services - these questions are sidelined and dealt with by ameliorative processes of 'adjustment' to provide a welfare bridge. The more substantial question, however, of how Australia as a nation considers its agricultural industries to exist alongside its extensive commitments to the environment, remain unanswered.

\section{References}

[1] ABS/ABARE/BRS, Socio-economic context for the Murray-Darling Basin, Descriptive Report to the Murray-Darling Basin Authority, Canberra: ABS/ABARE/BRS, 2009.

[2] Hajkowicz, S, Hatton T, Meyer W, McColl J, and Young M, 'Conceptual framework for planned landscape change' Agriculture for the Australian Environment - 2002 Fennar Conference on the Environment. 2002. http://www.csu.edu.au/special/fenner/papers/ref/07\%20Hajkowicz\%20Stef an.pdf (accessed February 27, 2010).

[3] Northern Victorian Irrigation Renewal Project, Rochester Works Projects. http://www.nvirp.com.au/downloads/The_Project/Maps/Rochester.pdf (accessed April 25, 2011).

[4] Victorian Farmers Federation, 'Keep it balanced Minister' Victorian Farmers Federation. 26 May 2010. http://www.vff.org.au/main/index.php? option $=$ com_content\&task=view\&id=892\&Itemid $=49$.

[5] ABC 'ABC News' ABC News [online], 3 June 2010 http://www.abc.net.au/ news/stories/2010/06/03/2917358.htm.

[6] Lloyd, G, 'Great dividing rage over water' The Australian, 23 October 2010. <www.theaustralian.com.au/news/opinion/great-dividing-rage-overwater/story-e6frg6zo-1225942074914> (accessed November 17, 2010).

[7] 'The drought breaks' The Australian,. 13 November 2010. www.theaustralian.com.au/national-affairs/the-drought-breaks/storyfn59niix-1225952583089 (accessed November 13, 2010).

[8] Murray-Darling Basin Ministerial Council, An Audit of Water Use in the Murray-Darling Basin, Murray-Darling Basin Ministerial Council, 1995.

[9] Murray-Darling Basin Ministerial Council, Review of the Operation of the Cap August, Murray-Darling Basin Ministerial Council, 2000. 
[10] Murray-Darling Basin Ministerial Council, Setting the Cap - Report of the Independent Audit Group, Murray-Darling Basin Ministerial Council, 1996.

[11] Department of Sustainability and Environment, Our Water Our Future: Securing Our Water Future Together, White Paper, Melbourne: State Government of Victoria, 2004.

[12] Department of Sustainability and Environment, Protecting the Food Bowl's future, Melbourne: State Government of Victoria, 2008.

[13] Council of Australian Governments, 'Meeting Communique Adelaide' Department of the Prime Minister, 26 March 2008. http://www.pm.gov.au/ media/Release/2008/media_release_0147.cfm (accessed April 9, 2008).

[14] Wong, P, 'We'll get water right' The Weekly Times, p.17 2 April 2008

[15] Murray-Darling Basin Authority, Development of Sustainable Diversion Limits for the Murray-Darling Basin, Issues Paper, Canberra: Commonwealth of Australia, 2009.

[16] Murray-Darling Basin Authority, Guide to the proposed Basin Plan. Canberra: Commonwealth of Australia, 2010.

[17] Cooper, H, 'Murray-Darling plan gets fiery reception,' Lateline Australian Broadcasting Corporation, 14 October 2010. www.abc.net.au/lateline/ content/2010/s3038842.htm (accessed November 17, 2010).

[18] Wilson, L, 'Water cuts will go ahead despite impact study, says Murray Darling Basin chief', The Australian, 19 October 2010. www.theaustralian.com.au/national-affairs/water-cuts-will-go-aheaddespite-impact-study-says-Murray-Darling-basin-chief/story-fn59niix1225940632671 (accessed November 15, 2010).

[19] Ker, P, 'Murray-Darling chair resigns, leaving reforms in turmoil' The Age, 7 December 2010. http://www.theage.com.au/environment/waterissues/murraydarling-chair-resigns-leaving-reforms-in-turmoil-2010120718nea.html (accessed April 26, 2011).

[20] Kildea, P, and Williams, G, 'Professors Paul Kildea and George Williams, Gilbert and Tobin Centre of Public Law, UNSW' Submissions received by the Committee, 12 January 2011. http://www.aph.gov.au/senate/committee /rat_ctte/mdb/submissions.htm (accessed April 26, 2011).

[21] Senate, Parliament of Australia, The management of the Murray-Darling Basin, 26 April 2011. http://www.aph.gov.au/senate/committee/rat_ctte/ mdb/index.htm (accessed April 26, 2011).

[22] Hoekstra, A K, 'Virtual Water Trade Proceedings of the International Expert Meeting on Virtual Water Trade' Value of Water Research Report Series No 12. 2003.

[23] Sprague, J, 'Want a piece of the agricultural action?' The Australian Financial Review, 2, 9-10 April 2011

[24] Rochford, F, 'The limits on the human right to water' Australian Journal of Human Rights, 109-133 2011.

[25] Constanza, R, 'Visions of alternative (unpredictable) futures and their use in policy analysis' Conservation Ecology, 2000. 
[26] Howden, M S, and O'Leary G J 'Evaluating options to reduce greenhouse gas emissions from an Australian temperate wheat cropping systems' Environmental Modelling and Software, 169-176 1997.

[27] Ugalde, D. Brungs A, Kaebernick M, McGregor A, and Slattery B, 'Implications of climate change for tillage practice in Australia' Soil and Tillage Research, 318-330, 2007.

[28] Adamson, D, Quiggan, J, and Mallawaarachchi, T, 'Modelling basin level allocation of water in the Murray Darling Basin in a world of uncertainty' 49th Annual Conference of the Australian Agricultural and Resource Economics Society, Coffs Harbour NSW, 2005.

[29] Carberry, P, Keating, B, Bruce, S, and Walcott J, Technological innovation and productivity in dryland agriculture in Australia Canberra: ABAREBRS, CSIRO, 2010.

[30] Department of Foreign Affairs and Trade 'Agriculture and the WTO' Department of Foreign Affairs and Trade http://www.dfat.gov.au/trade/ negotiations/trade_in_agriculture.html (accessed June 8, 2010).

[31] OECD, OECD Agricultural Policies 2004 at a Glance, Paris: Organization for Economic Co-operation and Development Publications, 2004.

[32] Environmental Working Group, 'Farm Subsidy Database' Environmental Working Group. http://farm.ewg.org.regionsummary.php?fips $=00000 \&$ statename $=$ theUnited States (accessed June 8, 2010).

[33] Abler, D, 'Multifunctionality, agricultural policy, and environmental policy' Agricultural and Resource Economics Review, 8-17, 2004.

[34] Cocklin, C, Dibden, J, and Mautner, N, 'From market to multifunctionality? Land stewardship in Australia' The Geographical Journal, 197-205, 2006.

[35] Armstrong v United States. 364 US 40 (1960).

[36] Callaway, J M, and McCarl, B, 'The economic consequences of substituting carbon payments for crop subsidies in US agriculture' Environmental and Resource Economics, 15-43, 1996.

[37] Greiner, R, and Gregg D, 'Farmers' intrinsic motivations, barriers to the adoption of conservation practices and effectiveness of policy instruments: Empirical evidence from northern Australia' Land Use Policy, 2010 (in press). 